FORSKNING

Denne artikkelen finnes også i engelsk utgave. Publiserings dato: 22.03.2022

\title{
Sykepleieres vurderinger av kurset «Fire gode vaner» - en tverrsnittsstudie
}

\section{Eva Saltrøe}

Fagutviklingssykepleier

Bærum sykehus

\section{Monica Aas}

Forsker

Forsknings- og utviklingsavdelingen, Klinikk for psykisk helse og rus, Vestre Viken

\section{Bror Just Andersen}

Spesialrådgiver/prosjektleder

Forsknings- og utviklingsavdelingen, Klinikk for psykisk helse og rus, Vestre Viken

Personorientert kommunikasjon

Kommunikasjonsferdigheter

Undervisning

Klinisk kompetanse

Tverrsnittsstudie

Sykepleien Forskning 2021;16(87671):e-87671

DOI: 10.4220/Sykepleienf.2021.87671

\section{Sammendrag}


Bakgrunn: Ved å trene opp konkrete ferdigheter kan helsepersonell lære hvordan de systematisk kan kommunisere best mulig med pasienter og pårørende. «Fire gode vaner» (4GV) er en metode og kursmodell som er utviklet av Kaiser Permanente i USA, som omhandler teknikker for å lytte til og søke forståelse for pasientenes perspektiv, være tydelig empatisk i pasientmøter, sikre at de har forstått og husker informasjon de har mottatt, og gjøre dem delaktige i behandlingen. Per 2021 inngår 4GV som et fast internt kommunikasjonskurs på sju norske sykehus, både som rene legekurs og som tverrfaglige kurs.

Hensikt: Hensikten med studien var å unders $\varnothing$ ke om sykepleiere vurderte at kurset økte deres kommunikasjonskompetanse og medførte endring av deres egen kommunikasjonspraksis med pasienter.

Metode: Unders $\varnothing$ kelsen var en deskriptiv tverrsnittsstudie og en oppfølgingsevaluering av egenvurdering av kommunikasjonsstil før og etter et todagers tverrfaglig 4GV-kurs. For å besvare hensikten samlet vi inn data på to måter: Delstudium 1: Evaluering med spørreskjema av egenkompetanse i kommunikasjon før og etter 4GV-kurs fra 157 sykepleiere fra Bærum sykehus og Haukeland universitetssjukehus. Delstudium 2: Et detaljert nettbasert spørreskjema 3-24 måneder etter fullført kommunikasjonskurs i metoden 4GV. Totalt 91 sykepleiere fra de to sykehusene besvarte nettskjemaet.

Resultater: Analyse av begge unders $\varnothing$ kelsene viser at $4 \mathrm{GV}$ ga sykepleierne $\varnothing \mathrm{kt}$ kommunikasjonskompetanse og medførte endret kommunikasjon med pasienter. Endringene ble en naturlig del av sykepleiernes praksis og handlet særlig om å være bevisst på pasientperspektivet ved å benytte åpne spørsmål, lytte aktivt og strukturere pasientsamtaler. Alle fire vanene synes å være tilnærmet like nyttige. Sykepleierne etterlyste repetisjon av kurset og økt implementering av metoden.

Konklusjon: Funnene i denne studien viser at et todagers tverrfaglig kommunikasjonskurs etter metoden $4 \mathrm{GV}$ medførte at sykepleiere $\varnothing \mathrm{kte}$ sin kommunikasjonskompetanse, og dermed endret sin kommunikasjon i praksis.

Kommunikasjon er beskrevet som grunnsteinen i sykepleie (1) og inngår i alle deler av yrkespraksis - fra Kari Martinsens beskrivelse «å se med hjertets фye» (2) til krav om å styrke brukerens deltakelse i sin egen behandling gjennom samvalg (3). 
Sykepleiere skal beherske god klinisk kommunikasjon, fremstå som omsorgsfulle og kommunisere profesjonelt. Det innebærer faglig, personorientert og helsefremmende kommunikasjon (1), som skal tilpasses pasientens evne til å gi og motta informasjon (4).

Vi vet at når helsepersonell lykkes i å informere om diagnose, årsak og forventet varighet av symptomer slik at pasienten forstår det, gir det $\varnothing \mathrm{kt}$ pasienttilfredshet, $\varnothing \mathrm{kt}$ etterlevelse, bedre oppfølging av behandling og redusert risiko for feilbehandling (5-8).

Som sykepleiere opplever vi situasjoner der vi kjenner oss trygge og kompetente i samtalerollen. Men vi erfarer også situasjoner der kommunikasjonen blir vanskelig. Det kan være samtaler med mål om pasientmedvirkning som krever planlegging og kjennskap til pasienten, eller samtaler preget av sterke følelser som krever tydelig empati fra sykepleieren.

For mange pasienter er opplevelsen av at helsepersonell kjenner dem som person, viser omsorg og fremstår tillitsskapende, avgjørende for at de skal våge å stille de vanskelige spørsmålene. Da blir nettopp det å vise empati en av de sterkeste interaksjonene helsepersonell kan gjøre (9-11).

Pasientmedvirkning vanskeliggjøres når avgjørelser tas av flere personer og over et tidsrom som strekker seg ut over én konsultasjon eller samtale (12). Dette er særlig krevende ved akutt sykdom (13) og krever godt samarbeid innad i behandlingsteamet (14).

Sykepleiere i Norge etterlyser faglig påfyll i kommunikasjonskompetanse (15). Tidligere ble kommunikasjon oppfattet som en personlig egenskap, men i dag anses det som en ferdighet som kan læres (16-18).

For å lykkes med kommunikasjonstrening i større organisasjoner er det viktig med standardisert instruktørutdanning og prioritering på organisasjonsnivå $(11,19)$.

\section{«Fire gode vaner», 4GV}

4GV er en metode og et kommunikasjonskurs som ble utviklet på oppdrag fra det private amerikanske helsesystemet Kaiser Permanente i 1999. 4GV tar utgangspunkt $\mathrm{i}$ at helsepersonell bevisst og ubevisst innarbeider seg kommunikasjonsmønster og vaner (16). Kurset bygger på fire gode vaner for kommunikasjon mellom helsepersonell og pasient:

- Vane 1: Invester i begynnelsen

- Vane 2: Utforsk pasientperspektivet 
- Vane 3: Vis empati

- Vane 4: Invester i avslutningen

Målet er bedre pasienttilfredshet, økt etterlevelse av behandling og færre klager og konflikter (20). Kurset går over to dager og omfatter både plenumsundervisning og gruppearbeid med rollespill. 4GV ble opprinnelig utformet for legeprofesjonen, og en observasjonsstudie av kurset i USA viste positiv effekt på både pasient- og legetilfredshet (6).

Kurset er tilpasset norske forhold av Pål Gulbrandsen og Arnstein Finset, og studier i Norge har vist $\varnothing \mathrm{kt}$ kommunikasjonskompetanse og mestringsf $\varnothing l e l s e$ blant leger $(20,21) .4 \mathrm{GV}$ ble opprinnelig bygget opp rundt en tenkt legekonsultasjon med en pasient som kunne redegjøre for sitt syn og sine behov.

Tilpassing av kurset til en tverrfaglig deltakergruppe har i stor grad vært gjennomført av instruktørene på de ulike sykehusene. Til tross for en felles mal for kurset er det nødvendigvis forskjeller i hva som sies, og hvordan det vektlegges.

Det finnes få studier som omhandler effekten av 4GV hos sykepleiere internasjonalt, og ingen studier er gjennomført i Norge. En amerikansk studie viser at sykepleiere opplever nytte av metoden selv etter kun én times undervisning (22), mens en afrikansk studie konkluderer med at kurset ikke $\varnothing$ ker praktisk empati hos sykepleier- og jordmorstudenter (23).

Studier på andre liknende kommunikasjonskurs viser $\varnothing \mathrm{kt}$ egenvurdert kommunikasjonskompetanse (24-26). Flere studier er derfor nødvendig for å unders $\varnothing$ ke nytten av 4GV-kurset for sykepleiere.

4GV er per 2021 implementert som et fast, internt kommunikasjonskurs på sju norske sykehus. Det er Diakonhjemmet, Akershus universitetssykehus, Sykehuset i Vestfold, Sykehuset Telemark, Universitetssykehuset Nord-Norge og sykehusene vi har benyttet i denne studien: Bærum sykehus og Haukeland universitetssjukehus.

Begge sykehusene utdanner sine egne instruktører og har gjennomført kurs fra 2015. De tilbyr tverrfaglige kurs, og om lag 60 prosent av deltakerne er sykepleiere. Det har vært behov for å tilpasse kurset gjennom å endre søkelyset fra legekonsultasjoner og samtaler mellom lege og pasient til ulike pasientmøter med flere profesjoner eller helsepersonell på sykehus.

Begge sykehusene benytter faste evalueringsskjema før og etter kursene, og i denne studien har vi kunnet benytte disse for å sammenlikne sykepleiernes egenvurderte kommunikasjonskompetanse. 


\section{Hensikt}

Hensikten med studien var å unders $\varnothing$ ke om sykepleiere som gjennomførte et todagers tverrfaglig 4GV-kurs, økte sin kommunikasjonskompetanse, benyttet metoden i praksis og dermed opplevde en endring i sin kommunikasjon med pasienter. For å besvare dette har delstudiene målt egenvurdert kommunikasjonskompetanse ved tre tidspunkt, (delstudium 1 og 2) og om kurset er tilpasset sykepleiere i ulike deler av sykehuset (delstudium 2).

\section{Metode}

\section{Design}

I studien har vi anvendt to ulike datainnsamlinger: en pre-post-studie som viser resultater før og etter at 4GV-kurs er gjennomført (delstudie 1), og en tverrsnittsstudie hvor vi innhentet data 3-24 måneder etter gjennomført kurs (delstudie 2). Designet har som mål å beskrive endring og utforske sammenhenger basert på deltakernes selvrapportering om oppfatninger, holdninger, atferd, opplevelser og preferanser (27).

\section{Utvalg}

Alle sykepleierne som var ansatt ved Bærum sykehus og Haukeland universitetssjukehus våren 2020, og som hadde gjennomført 4GV i perioden 20152019, ble invitert til å delta. Grunnet svært lav svarprosent fra kursdeltakere i 20152017 benyttet vi i studien kun svar fra 2018 og 2019. Det betyr at respondentene svarte på egenvurdert kommunikasjonskompetanse 3-24 måneder etter at de hadde gjennomført kurset.

Det er samme populasjon i begge gruppene (sykepleiere ansatt på sykehuset $\mathrm{i}$ perioden 2018-2019), men det er ikke nødvendigvis de samme sykepleierne som har fylt ut skjemaet i begge datainnsamlingene (figur 1).

Figur 1. Egenvurdert kommunikasjonskompetanse målt på tre tidspunkter

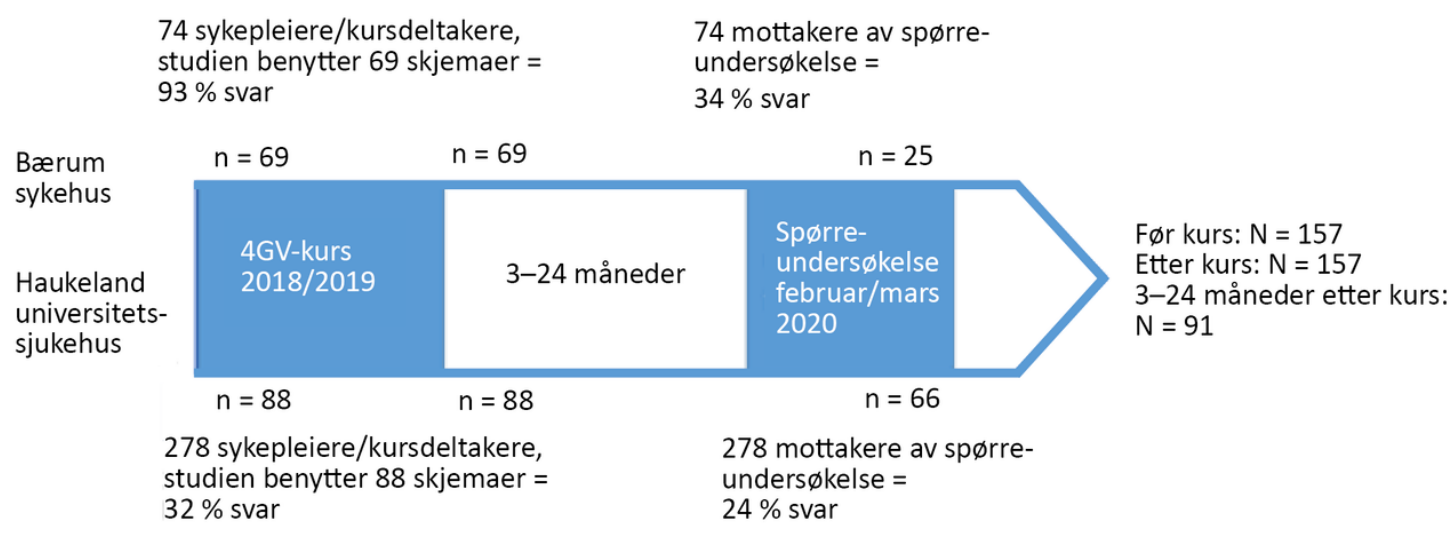




\section{Datainnsamling}

Delstudie 1: Studien omfattet anonyme data fra kontinuerlig kartlegging som begge sykehusene benyttet umiddelbart før og etter at kursene var gjennomf $\varnothing \mathbf{r t}$, og ble innhentet i 2018-2019.

Delstudie 2: Datainnsamlingen foregikk fra 25. februar til 19. mars 2020. Vi benyttet et anonymt spørreskjema. Vi sendte invitasjon per e-post til arbeidsstedet, og respondentene ga informert samtykke til deltakelse ved å besvare spørreskjemaet. Koronapandemien krevde store ressurser på begge sykehusene fra slutten av februar 2020, og innhenting av spørreskjemaene ble avsluttet vesentlig tidligere enn vi hadde planlagt.

Fra delstudie 1 og 2 har vi benyttet fire likelydende påstander for å sammenlikne egenvurdert kommunikasjonskompetanse før, umiddelbart etter og 3-24 måneder etter at kurset var gjennomført.

Spørreskjemaet i delstudie 2 ble utarbeidet i Nettskjema (28). Spørsmålsutvalget baserte vi på to skjemaer som var utviklet for å evaluere kommunikasjonskurset 4GV: «Long-term effect of communication training on the relationship between physicians' self-efficacy and performance» (21) og evalueringsskjemaet fra delstudie 1 som benyttes før og etter at kurset er gjennomført (vedlegg 1).

Spørreskjemaet inneholdt 23 spørsmål og omhandlet nytte av undervisningselementer, nytte i praksis, egenvurdering av kommunikasjonskompetanse, om respondentene vurderte at de hadde endret kommunikasjon etter kurset, og om kommunikasjonskurs kan gi bedre kommunikasjon med pasienter.

I tillegg innhentet vi sosiodemografiske variabler: sykehus og avdelingstilhørighet, tidspunkt for kursgjennomføring, erfaringsbakgrunn ved kursgjennomføring og søkelys på metodene fra $4 \mathrm{GV}$ ved arbeidsplassen.

Tjue spørsmål var utformet som avkrysningsspørsmål og matrisespørsmål med svarkategorier basert på Likert-skalaen og tallvurdering fra o til 10.

Kommunikasjonskompetanse ble målt i påstander under «Hvor sikker er du på at du på en vellykket måte kan utføre hver av de følgende oppgavene?» med svaralternativene $1-10$ ( 1 = slett ikke sikker, 10 = svært sikker $)$.

Vi sammenliknet fire likelydende påstander i delstudie 1 og 2 . For å teste intern konsistens i spørreskjemaet benyttet vi analyse med Cronbachs alfa. Total $\alpha=0,90$, som tilsvarer høy samvariasjon og god intern reliabilitet (29). Piloten på spørreskjemaet ble utført blant seks sykepleiere som hadde gjennomført 4GV på andre sykehus enn Bærum eller Haukeland. 


\section{Dataanalyse}

Dataene ble analysert ved hjelp av statistikkprogrammet SPSS Statistics 26.

Resultatene fra delstudie 1: Dataene møtte ikke kravet om normalfordeling. Vi benyttet derfor Wilcoxon signed-rank test for å unders $\varnothing$ ke forandring $\mathrm{i}$ respondentenes egenvurdering av kommunikasjonsteknikker på en kontinuerlig skala før og rett etter at de hadde gjennomført 4GV-kurs.

Resultatene fra delstudie 2: Kategoriske variabler ble målt med kjikvadrattester. Resultatene blir presentert ved hjelp av beskrivende statistikk, antall og prosenter. To spørsmål hadde åpne svarkategorier for å kunne utdype hva og hvorfor respondentene eventuelt hadde endret sin kommunikasjon, og ett spørsmål ga mulighet til å gi en annen tilbakemelding.

\section{Etiske overveielser}

I forkant av studien knyttet vi etiske vurderinger til datainnsamling, og vi gjennomførte spørreunders $\varnothing$ kelser i henhold til etiske prinsipper for konfidensialitet, informert samtykke og ivaretakelse av forskningspersonens integritet (27).

Ettersom vi i studien benyttet nettbaserte spørreskjema med spørsmål som vi ikke vurderte som reaktiverende, og svarene ble anonymisert, vurderte vi at dette var innenfor etiske konvensjoner for kvantitativ forskning.

Studien ble godkjent av Norsk senter for forskningsdata (prosjektnummer 857834), Universitetet i Oslo samt ledelsen og personvernombudet ved Bærum sykehus og Haukeland universitetssjukehus.

Det er viktig å fremheve at studien analyserer endringer etter kurset, og ikke den jobben eller innsatsen enkeltpersoner har utført (27). For å ivareta personvernet blir alle resultater presentert samlet, og studien vurderer kursene og sykehusene under ett.

Førsteforfatteren er fagutviklingssykepleier med erfaring fra medisinsk sengepost og er instruktør i 4GV. Kunnskap om undervisning og implementering av 4GV har vært en del av forforståelsen.

\section{Resultater}

Ved delstudie 1 ble totalt 157 evalueringsskjema (69 fra Bærum og 88 fra Haukeland) utfylt av deltakerne umiddelbart før og etter at de hadde gjennomført 4GV-kurs i 2018-2019. 
Ved delstudie 2 sendte vi e-post med lenke til et nettbasert spørreskjema til totalt 352 sykepleiere, hvorav 91 (26 prosent) svarte. Av disse var 66 ansatt på Haukeland universitetssjukehus (24 prosent svar) og 25 ansatt på Bærum sykehus (34 prosent svar).

\section{Bakgrunnsvariabler fra delstudie 2}

Respondentene var fordelt på følgende avdelinger: 29 i sengepost, 21 i poliklinikk, sju arbeidet på flere seksjoner eller avdelinger, én jobbet i akuttmottak, elleve jobbet innen operasjon/intensiv og 19 arbeidet $\mathrm{i}$ andre seksjoner eller avdelinger, blant annet rus, psykiatri og føde/barsel.

Tre personer manglet informasjon om arbeidssted. Totalt 77 respondenter hadde over fem års erfaring som sykepleier da de gjennomførte kurset, 13 hadde to-fem års erfaring, mens kun én hadde under ett års erfaring.

\section{Endring av kommunikasjon etter gjennomgått kurs fra delstudie 2}

Unders $\varnothing$ kelsens hovedsp $\varnothing$ rsmål var om sykepleierne opplevde endring i sin kommunikasjon etter å ha gjennomført kurset. Totalt 77 prosent svarte «Delvis» eller «Ja» på dette spørsmålet. Av de som jobbet på sengepost og poliklinikk, svarte 87 prosent «Delvis» og «Ja», og på akuttmottak, operasjons- og intensivavdelinger svarte 58 prosent «Delvis» og «Ja».

Det var en tendens til at deltakerne som jobbet ved sengeposter og poliklinikker, rapporterte større endring i kommunikasjon (delvis eller helt) enn deltakere ved akuttmottak og intensivavdelinger eller de som jobbet ved flere avdelinger $\left(\mathrm{X}_{2}=\right.$ $7,2, p=0,07)$.

Hele 92 prosent oppga at de husket vanene de lærte ved å delta på 4GV-kurset 3-24 måneder etter kurset, og 99 prosent mente at å delta på 4GV-kurs forbedret kommunikasjonsevnene. På spørsmål om de snakket om 4GV på avdelingen, svarte 75 prosent «Delvis» eller «Ja».

\section{«99 prosent mente at å delta på 4GV-kurs forbedrer kommunikasjonsevnene.»}

En statistisk signifikant sammenheng ble observert mellom det å snakke om 4GVkurset på avdelingen og endret kommunikasjon 3-24 måneder etter kurset. Hele 87 prosent av de som rapporterte at det ble snakket om $4 \mathrm{GV}$ på avdelingen, endret kommunikasjonsstilen, mens i avdelinger der det ikke ble snakket om kurset, endret 45 prosent kommunikasjonsstil etter kurset (X2 = 16,19, $\mathrm{p}<0,001)$. 
Av respondentene svarte 21 «Nei» på om de hadde endret sin kommunikasjon. Blant disse hadde 19 mer enn fem års erfaring da de tok kurset, og samtlige mente at man kan bli bedre i kommunikasjon ved å gå på kurs.

I de åpne spørsmålene oppga 10 av de 21 respondentene at de ikke hadde endret sin kommunikasjon fordi de kunne det fra før, og at kurset var en bekreftelse på at de allerede hadde god kommunikasjon.

\section{Betydningen av de fire vanene og undervisningsmetoder (delstudie 2)}

Mellom 71,4 og 80,2 prosent av deltakerne vurderte de fire vanene som nyttige eller svært nyttige, mens å investere i avslutningen og få frem pasientperspektivet fikk høyest skår. Videre viste nyttevurderingen av de ulike undervisningselementene at sykepleierne vurderte rollespill som noe mer nyttig enn plenumsundervisning (tabell 1).

Tabell 1. Vurdering av nytten av de ulike elementene på kurset $(N=91)$

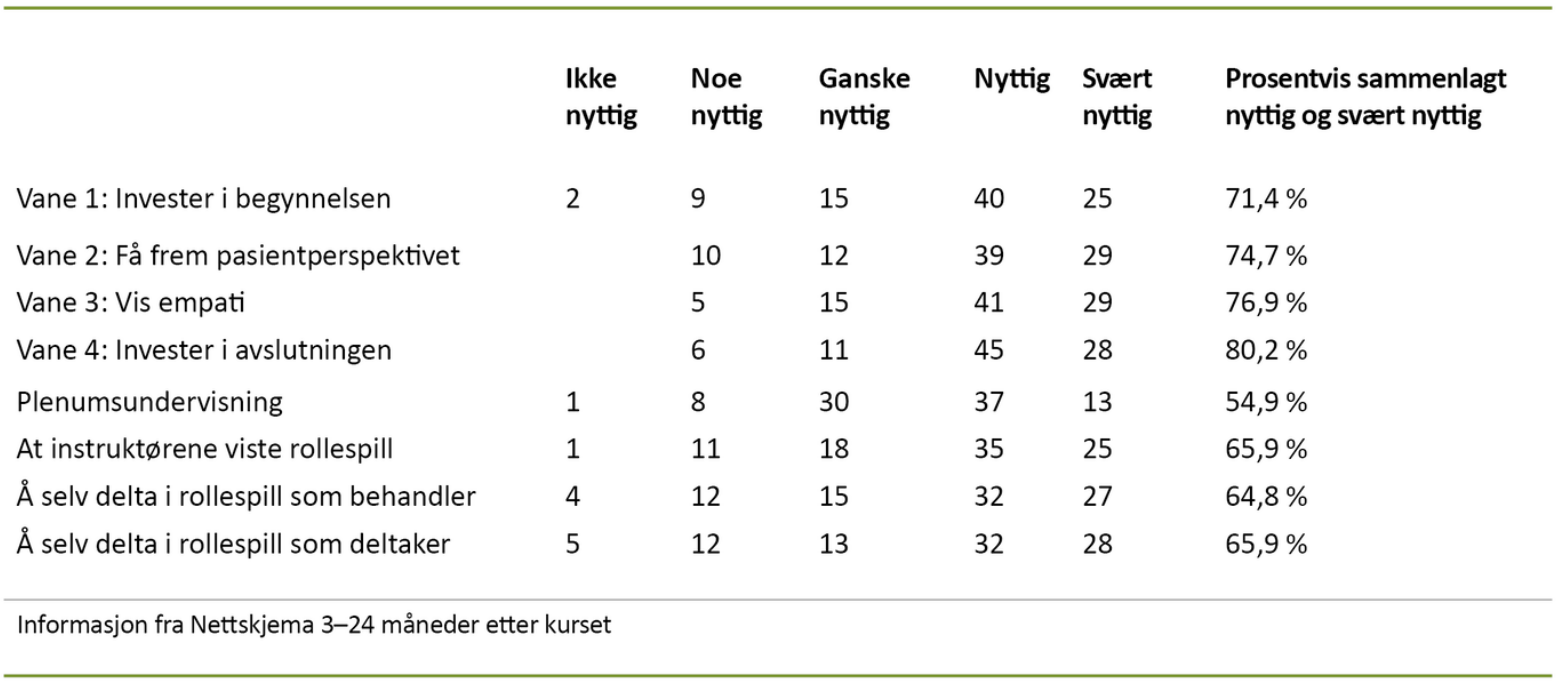

\section{Arbeidet med pasienter etter gjennomgått kurs og praktisk nytte av 4GV (delstudie 2)}

Som vist i tabell 2 rapporterte over halvparten av deltakerne at det var lettere å unngå misforståelser i arbeidet med pasienter 3-24 måneder etter å ha deltatt på 4GV-kurs. Det var lettere å få frem viktig bakgrunnsinformasjon, og i tillegg virket pasienter og pårørende mer fornøyd. Kun én respondent mente at 4GV kompliserte praksis (tabell 2). 
Tabell 2. Arbeidet med pasienter etter deltakelse på kurset $(N=91)$

\begin{tabular}{|c|c|c|c|c|c|c|}
\hline & $\begin{array}{l}\text { Helt } \\
\text { uenig }\end{array}$ & Uenig & Både og & Enig & Helt enig & $\begin{array}{l}\text { Prosentvis sammenlagt } \\
\text { enig og helt enig }\end{array}$ \\
\hline Det har vært lettere å unngå misforståelser & & 8 & 35 & 38 & 10 & $52,7 \%$ \\
\hline $\begin{array}{l}\text { Samtalene har blitt mer effektive med } \\
\text { hensyn til tidsbruk og utfall }\end{array}$ & & 13 & 42 & 29 & 7 & $39,6 \%$ \\
\hline Pasienter og pårørende virker mer fornøyde & & 12 & 37 & 32 & 10 & $46,2 \%$ \\
\hline $\begin{array}{l}\text { Jeg får lettere frem viktig bakgrunns- } \\
\text { informasjon }\end{array}$ & & 9 & 31 & 40 & 11 & $56,0 \%$ \\
\hline Det har komplisert arbeidet mitt & 35 & 37 & 18 & 1 & & $1,0 \%$ \\
\hline $\begin{array}{l}\text { De endringer jeg } \emptyset \text { nsket å få til etter kurset, } \\
\text { har blitt en naturlig del av min praksis }\end{array}$ & 1 & 12 & 39 & 27 & 12 & $42,9 \%$ \\
\hline
\end{tabular}

Informasjon fra Nettskjema 3-24 måneder etter kurset

\section{Egenvurdering av kommunikasjonskompetanse (delstudie 1 og 2)}

Evaluering av egenkompetanse i kommunikasjonsferdigheter ble betydelig bedre etter gjennomgått 4GV-kurs (tabell 3 og 4). Etter å ha fullført 4GV-kurset rapporterte deltakerne at de fikk høyere kompetanse i å innlede en samtale med en pasient om hans eller hennes bekymringer, bedre ferdigheter i formidling av en dårlig nyhet til en pasient eller pårørende, bedre evne til å utforske intense følelser hos en pasient og kompetanse i behandlingsplan.

Delstudie 2 viser også høyere evaluering av egenkompetanse i kommunikasjon 3-24 måneder etter kurset.

Tabell 3. Sammenlikning av selvvurdert kommunikasjonskompetanse fra evalueringsskjemaet $f \varnothing r$ og etter kurset og fra spørreunders $\varnothing$ kelsen

\begin{tabular}{|c|c|c|c|c|c|c|c|c|c|c|c|c|}
\hline \multirow{2}{*}{$\begin{array}{l}\text { Spørsmål } \\
\text { Hvor sikker er du på at du på en } \\
\text { vellykket måte kan utføre } \\
\text { følgende oppgaver } \\
1=\text { slett ikke sikker, } \\
10=\text { svært sikker }\end{array}$} & \multicolumn{3}{|c|}{$\begin{array}{l}\text { Vurdert } \\
\text { egenkompetanse } \\
\text { som lav } \\
\text { (skår fra } 1 \text { til 4) }\end{array}$} & \multicolumn{3}{|c|}{$\begin{array}{l}\text { Vurdert } \\
\text { egenkompetanse } \\
\text { som middels } \\
\text { (skår fra } 5 \text { til 7) }\end{array}$} & \multicolumn{3}{|c|}{$\begin{array}{l}\text { Vurdert } \\
\text { egenkompetanse } \\
\text { som høy } \\
\text { (skår fra } 8 \text { til 10) }\end{array}$} & \multicolumn{3}{|c|}{$\begin{array}{l}\text { Prosentvis andel som } \\
\text { skårer egenvurdert } \\
\text { kompetanse som høy } \\
\text { (skår fra } 8 \text { til 10) }\end{array}$} \\
\hline & $\mathrm{F}^{*}$ & $E^{* *}$ & $\mathrm{~S}^{* * *}$ & $\mathrm{~F}$ & $E$ & $\mathrm{~S}$ & $\mathrm{~F}$ & $E$ & $\mathrm{~S}$ & $\mathrm{~F}$ & $E$ & $\mathrm{~S}$ \\
\hline $\begin{array}{l}\text { Innlede en samtale med en } \\
\text { pasient om hans eller hennes } \\
\text { bekymringer }\end{array}$ & 21 & 1 & 3 & 96 & 47 & 19 & 40 & 109 & 69 & $25,5 \%$ & $69,4 \%$ & $75,8 \%$ \\
\hline $\begin{array}{l}\text { Formidle en dårlig nyhet til } \\
\text { en pasient / pårørende }\end{array}$ & 53 & 7 & 10 & 86 & 71 & 35 & 18 & 97 & 47 & $11,5 \%$ & $61,7 \%$ & $51,6 \%$ \\
\hline $\begin{array}{l}\text { Utforske intense følelser hos } \\
\text { en pasient, for eksempel sinne }\end{array}$ & 46 & 13 & 12 & 92 & 74 & 38 & 19 & 70 & 41 & $12,1 \%$ & $44,5 \%$ & $45,0 \%$ \\
\hline $\begin{array}{l}\text { Avslutte en samtale/time/ } \\
\text { innleggelse med et resyme av } \\
\text { problemene og en behandlingsplan }\end{array}$ & 27 & 2 & 3 & 103 & 46 & 22 & 27 & 109 & 66 & $17,2 \%$ & $69,4 \%$ & $72,5 \%$ \\
\hline \multicolumn{13}{|c|}{$\begin{array}{ll}\text { Sammenlikning av egenvurdert kompetanse mellom to uavhengige gru } \\
\text { - } & * \mathrm{~F}=\text { evalueringsskjema umiddelbart før kurset, } \mathrm{N}=157 \\
\text { - } & * * \mathrm{E}=\text { evalueringsskjema umiddelbart etter kurset, } \mathrm{N}=157 \\
\text { - } & * * * \mathrm{~S}=\text { sp } \varnothing \text { rreunders } \varnothing \text { kelse, Nettskjema 3-24 måneder etter }\end{array}$} \\
\hline
\end{tabular}


Tabell 4. Forandring i selvvurdert kommunikasjonskompetanse før og rett etter kurset fra evalueringsskjemaet $(\mathrm{N}=157)$

\begin{tabular}{|c|c|c|c|}
\hline Før kurset & Etter kurset & Statistikk* & \\
\hline $\begin{array}{l}\text { Innlede en samtale med en pasient om hans eller hennes } \\
\text { bekymringer, Median (min.--maks. skår) }\end{array}$ & $7(3-10)$ & $8(4-10)$ & Z-skår $=-10,92, p<0,001$ \\
\hline $\begin{array}{l}\text { Formidle en dårlig nyhet til en pasient / pårørende, } \\
\text { Median (min.-maks. skår) }\end{array}$ & $5(2-10)$ & $8(2-10)$ & Z-skår $=-9,15, p<0,001$ \\
\hline $\begin{array}{l}\text { Utforske intense følelser hos en pasient, f.eks. sinne, } \\
\text { Median (min.--maks. skår) }\end{array}$ & $5(1-9)$ & $7(2-10)$ & Z-skår $=-7,84, p<0,001$ \\
\hline $\begin{array}{l}\text { Avslutte samtale/time/innleggelse med et resyme av } \\
\text { problemene og en behandlingsplan, Median (min.-maks. skår) }\end{array}$ & $6(2-10)$ & $8(4-10)$ & Z-skår $=-8,93, p<0,001$ \\
\hline
\end{tabular}

*Wilcoxon signed-rank test. Medianskår og minimum- til maksimumskår. Data fra evalueringsskjemaet før og etter kurs. Skår på spørsmålet «Hvor sikker er du på at du kan utføre følgende oppgaver på en skala fra 1 (slett ikke sikker) til 10 (svært sikker)»? Samme sykepleiere deltok før og etter evalueringen.

\section{Åpne svar 3-24 måneder etter kurset (delstudie 2)}

På spørsmål om hva sykepleierne hadde endret i sin kommunikasjon, svarte totalt 60 at de benyttet momenter fra alle vanene, i størst grad «å utforske pasientperspektivet» $(n=23)$. A tte beskrev endret samtalestruktur, og 18 listet opp minimum to momenter fra flere vaner.

\section{«De fleste beskrev at de har fătt $\emptyset \mathbf{k t}$ bevissthet om sin egen kommunikasjon, og at de ser effekt av metoden.»}

På et åpent spørsmål om hvorfor sykepleierne hadde endret sin kommunikasjon, svarte totalt 74 respondenter. De fleste beskrev at de har fått $\varnothing \mathrm{kt}$ bevissthet om sin egen kommunikasjon, og at de ser effekt av metoden. Det siste åpne spørsmålet gav mulighet for andre tilbakemeldinger. Totalt svarte 42, hvorav 23 etterlyste repetisjon og/eller $\varnothing \mathrm{kt}$ implementering i praksis.

\section{Diskusjon}

4GV-kurs har de siste årene vært et tilbud til sykepleiere på flere norske sykehus. Vi $\emptyset$ nsket derfor å undersøke om kurset medførte at sykepleieres egenvurderte kommunikasjonskompetanse endret seg.

Det har vi vurdert gjennom spørsmål om egenvurdert kommunikasjonskompetanse før og etter kurset, om kursinnholdet er tilpasset sykepleiere, samt organisatorisk forankring. Dette er det første norske studiet som unders $\varnothing$ ker effekten $4 \mathrm{GV}$-kurset har på sykepleieres kommunikasjonskompetanse. 
Totalt 77 prosent svarte at de hadde endret sin kommunikasjon etter kurset. Av de som svarte «Nei», utdypet 11 prosent at de allerede benyttet en slik type kommunikasjon. Dermed var det 88 prosent av sykepleierne som benyttet metoden 4GV eller liknende i sin kommunikasjon med pasienter og pårørende 3-24 måneder etter gjennomført 4GV-kurs.

En sykepleier forklarte hvorfor hun endret sin kommunikasjon: «Endret kommunikasjon fordi en ser at en med små grep kan utgjøre en stor forskjell i pasientkontakten» (sykepleier 1).

Sykepleiere på sengepost eller i poliklinikk anga i større grad at de endret sin kommunikasjon etter kurset, sammenliknet med sykepleiere på anestesi-, intensiveller operasjonsavdelinger. Årsaken til denne ulikheten fremkommer ikke i studien, men som instruktør i $4 \mathrm{GV}$ gjenkjenner førsteforfatteren problematikken.

\section{«Studiens funn kan indikere at kurset ennå ikke er tilstrekkelig tilrettelagt for sykepleiere innen enkelte avdelinger.»}

Erfaringer har vist at det kan være utfordrende for eksempel for operasjonssykepleiere å finne realistiske situasjoner fra sitt eget praksisfelt når de skal øve på rollespill både på vane to, «utforsk pasientperspektivet», og vane fire, «invester i avslutningen».

Nødvendigheten av at den situasjonen deltakerne skal øve på i rollespillet, både er realistisk med tanke på klinisk praksis og er tilpasset deltakernes kompetanse, kan være avgjørende for læring (25). Studiens funn kan indikere at kurset ennå ikke er tilstrekkelig tilrettelagt for sykepleiere innen enkelte avdelinger.

For å lykkes med kommunikasjonstrening er det nødvendig å implementere kurs og opplæring i organisasjonen (19). Studien finner en signifikant sammenheng ( $\mathrm{p}<$ 0,001) mellom å snakke om 4GV på avdelingen og endre sin kommunikasjon etter kurset.

Som en sykepleier skrev: «Vanskelig å få til endringer alene, hadde vært lettere hvis hele posten var med på det» (sykepleier 2). Det er derfor positivt at totalt 69 av 91 sykepleiere svarte «Delvis» eller «Ja» på om de snakket om eller arbeidet med 4GV på avdelingen.

Studien gir ikke svar på om dette er personavhengig eller systemavhengig, men å snakke om kurset på avdelingen ser altså ut til å øke den positive effekten av 4GV og bidra til at denne vedlikeholdes over tid. 
Egenvurdert kommunikasjonskompetanse før, umiddelbart etter og 3-24 måneder etter 4GV-kurs

Denne studien kan tyde på at 4GV-kurset fører til bedret kommunikasjonskompetanse, og at denne effekten er til stede opptil to år etter gjennomført kurs. Forskningsfunnene våre samsvarer med en studie i Danmark (n $>1000$ ).

Den danske studien av Wolderslund og medarbeidere (26) fant at bedrede kommunikasjonsferdigheter etter gjennomført kommunikasjonskurs var til stede seks måneder etter gjennomført kurs (26).

\section{«Denne studien kan tyde på at 4GV-kurset fører til bedret kommunikasjonskompetanse, og at denne effekten er til stede opptil to år etter gjennomført kurs.»}

Selv om effekten var noe svakere seks måneder etter kurset sammenliknet med rett etter kurset, skåret deltakerne likevel betydelig høyere ved oppfølging enn før kurset. Studien til Wolderslund og medarbeidere (26) inkluderte en bredere deltakergruppe enn det vi hadde, ved at den i tillegg til sykepleiere besto av leger, sykepleierstudenter, kiropraktorer og fysioterapeuter.

Wolderslund og medarbeidere (26) observerte en høyere bedring av kommunikasjonsferdigheter hos sykepleiere og fysioterapeuter enn hos de andre yrkesgruppene etter gjennomført kommunikasjonskurs. Det kan tyde på at kommunikasjonskurs som 4GV er spesielt nyttig for sykepleiere.

\section{Styrker og svakheter ved studien}

Dette er den første norske studien som unders $\varnothing$ ker langtidseffekten av 4GV-kurs for sykepleiere i Norge. Studien har tre målepunkter: umiddelbart før, umiddelbart etter og 3-24 måneder etter kurs.

Flere norske sykehus tilbyr 4GV-kurs, og studiens resultater vil derfor kunne ha klinisk verdi gjennom å indikere praktisk nytteverdi og muligheter for videreutvikling av kurset. Vi vurderer det også som en styrke at det deltok sykepleiere fra to ulike helseregioner.

En svakhet ved studien var lav svarprosent. I delstudie 2 responderte kun 26 prosent på spørreskjemaet. Det reduserer studiens eksterne validitet og gir lavere statistisk styrke i analysene (27). Det ideelle kunne kanskje ha vært å kombinere spørreskjemaet med pasientintervjuer eller en observasjonsstudie. 
En annen svakhet er at selv om alle som gjennomførte kurset, var sykepleiere fra to sykehus (Bærum eller Haukeland), er det ikke nødvendigvis de samme sykepleierne som deltok i delstudie 1 og 2.

\section{Konklusjon}

Funn fra denne studien viser at tverrfaglige kurs etter metoden 4GV medfører at sykepleiere $\varnothing$ ker sin kommunikasjonskompetanse og endrer sin kommunikasjon med pasienter etter kurset. Sykepleiere opplever at å benytte metoden $4 \mathrm{GV}$ kan gjøre det lettere å få frem viktige bakgrunnsopplysninger og unngå misforståelser, og pasientene virker mer fornøyde.

Det kan se ut til at instruktørene har lyktes i å tilrettelegge undervisningen for en tverrfaglig deltakergruppe, men det er forbedringsmuligheter særlig når det gjelder spesialsykepleiere på anestesi-, intensiv- eller operasjonsavdelinger.

Sykepleiere etterlyser repetisjon av kurset, og studien finner at kompetanse i å håndtere sterke følelser og benytte empati med fordel kan inngå i et repetisjonseller påbygningskurs. Resultatene støtter at tverrfaglig kommunikasjonskurs etter metoden 4GV er et godt tiltak for å øke kommunikasjonskompetansen hos sykepleiere over tid.

Vi ønsker å takke alle sykepleierne som deltok $i$ studien.

\section{Hva studien tilfører av ny kunnskap}

- «Fire gode vaner» er et ressurskrevende kurs som er utviklet for legeprofesjonen og tilpasset flere profesjoner på de sykehusene som holder tverrfaglige kurs.

- Vi ville unders $\varnothing$ ke om sykepleiere opplevde at kurset var tilpasset deres kliniske hverdag, og om deres egenvurderte kommunikasjonskompetanse ble bedre etter at kurset var gjennomført.

- De tverrfaglige kursene som holdes $\mathrm{i}$ «Fire gode vaner», er tilpasset sykepleiere. Kurset førte ifølge sykepleierne til forbedret kommunikasjonskompetanse, og de mente at det var en god måte å lære klinisk kommunikasjon på.

\section{Referanser}

1. Eide H, Eide T. Kommunikasjon i relasjoner - personorientering, samhandling, etikk. Oslo: Gyldendal Norsk Forlag; 2017.

2. Martinsen K. Øyet og kallet. Bergen: Fagbokforlaget; 2000. 
3. Elwyn G, Edwards A, Thompson R. Shared decision making in health care. Achieving evidence-based patient choice. 3. utg. Oxford: Oxford University Press; 2016.

4. Lov 2. juli 1999 nr. 63 om pasient- og brukerrettigheter (pasient- og brukerrettighetsloven). Tilgjengelig fra: https://lovdata.no/dokument/NL/lov/199907-02-63?q=pasient-\%200g\%20brukerrettighetsloven (nedlastet 07.10.2019).

5. Jackson JL, Chamberlin J, Kroenke K. Predictors of patient satisfaction. Social Science \& Medicine. 2001;52(4):609-20. DOI: 10.1016/sO277-9536(00)00164-7

6. Stein T, Frankel RM, Krupat E. Enhancing clinical communication skills in a large healthcare organization: a longitudinal case study. Patient Education and Counseling. 2005;58(1):4-12. DOI: 10.1016/j.pec.2005.01.014

7. Doyle C, Lennox L, Bell D. A systematic review of evidence on the links between patient experience and clinical safety and effectiveness. BMJ Open. 2013;3(1):e001570. DOI: 10.1136/bmjopen-2012-001570

8. Lang EV. A better patient experience through better communication. Journal of Radiology Nursing. 2012;31(4):114-9. DOI: 10.1016/j.jradnu.2012.08.001

9. Kennedy DM, Fasolino JP, Gullen DJ. Improving the patient experience through provider communication skills building. Patient Experience Journal Article. 2014;1(10). DOI: 10.35680/2372-0247.1009

10. Frankel RM, Beckman H. «Won't you be my doctor?»: four keys to a satisfying relationship in an increasingly virtual world. Journal of Patient Experience. 2020;7(6):851-5. DOI: $10.1177 / 2374373520957184$

11. Gulbrandsen P, Finset A. Skreddersydde samtaler - en veileder i medisinsk kommunikasjon. Oslo: Gyldendal Akademisk; 2014.

12. Ofstad EH, Frich JC, Schei E, Frankel RM, Benth JS, Gulbrandsen P. Clinical decisions presented to patients in hospital encounters: a cross-sectional study using a novel taxonomy. BMJ Open. 2018;8:e018042. DOI: 10.1136/bmjopen-2017$\underline{018042}$

13. Kvangarsnes M, Hole T, Bårdsgjerde EK, Landstad BJ. Pasientmedverknad ved akutt sjukdom - ein metasyntese av pasient- og helsepersonellerfaringar. Michael. 2020;17(24):77-93. 
14. Oxelmark L, Ulin K, Chaboyer W, Bucknall T, Ringdal M. Registered nurses' experiences of patient participation in hospital care: supporting and hindering factors patient participation in care. Scandinavian Journal of Caring Sciences. 2018;32(2):612-21. DOI: 10.1111/scs.12486

15. Vareide PK, Hofseth C, Norvoll R. Stykkevis og helt - sykepleieres arbeidsoppgaver, kompetanse og yrkesidentitet i sykehus. Trondheim: SINTEF Unimed Helsetjenesteforskning; 2001. Rapport STF78 A013406. A6677.

16. Frankel RM, Stein T. Getting the most out of clinical encounter: the four habits model. The Permanente Journal. 1999;3(3):79-89. DOI: 10.7812/TPP/99-020

17. Tjora A. Den moderne pasient. Oslo: Gyldendal Akademisk; 2008.

18. De Haes H, Bensing J. Endpoints in medical communication research, proposing a framework of functions and outcomes. Patient Education and Counseling. 2009;74(3):287-94. DOI: 10.1016/j.pec.2008.12.006

19. Ammentorp J, Bigi S, Silverman J, Sator M, Gillen P, Ryan W, et al. Upscaling communication skills training - lessons learned from international initiatives. Patient Education and Counseling. 2020;104(2):352-9. DOI: $\underline{10.1016 / j . p e c .2020 .08 .028}$

20. Jensen BF, Gulbrandsen P, Dahl FA, Krupat E, Frankel RM, Finset A. Effectiveness of a short course in communication skills for hospital doctors: result of a crossover randomized controlled trial (ISRCTN22153332). Patient Education and Counseling. 2010;84(2):163-9. DOI: 10.1016/j.pec.2010.08.028

21. Gulbrandsen P, Jensen BF, Finset A, Blanch-Hartigan D. Long-term effect of communication training on the relationship between physicians' self-efficacy and performance. Patient Education and Counseling. 2012;91(2):180-5. DOI: $\underline{10.1016 / j . p e c .2012 .11 .015}$

22. Fisher MJ, Broome ME, Friesth BM, Magee T, Frankel RM. The effectiveness of a brief intervention for emotion-focused nurse-patient communication. Patient Education and Counseling. 2014;96:72-8. DOI: 10.1016/j.pec.2014.04.004

23. Alhassan M. Effect of a 2-day communication skills training on nursing and midwifery student's empathy: a randomized controlled trial. BMJ Open. 2019;9:e023666. DOI: 10.1136/bmjopen-2018-023666 
24. Falch AL, Stubberud D-G, Gabrielsen AK, Karlsen M-MW, Leopolder ÅHM. Bedre pleie etter kommunikasjonskurs. Sykepleien. 2015;103(4):64-6. DOI: 10.4220/Sykepleiens.2015.53651

25. Gabrielsen AK, Karlsen M-MW, Falch AL, Stubberud D-G. Communication training course with simulation. Sykepleien Forskning. 2016;2(11):184-92. DOI: $\underline{10.4220 / \text { Sykepleienf.2016.57832en }}$

26. Wolderslund M, Kofoed P-E, Ammentorp J. The effectiveness of a personcentered communication skills training programme for the health care professionals of a large hospital in Denmark. Patient Education and Counseling. 2020;104(26):1423-3O. DOI: 10.1016/j.pec.2020.11.018

27. Polit DF, Beck CT. Nursing research: generating and assessing evidence for nursing practice. 10. utg. Philadelphia: Wolters Kluwer; 2017.

28. Universitetet i Oslo. Nettskjema. Oslo: Universitetet i Oslo; u.å. Tilgjengelig fra: https://www.uio.no/tjenester/it/adm-app/nettskjema/ (nedlastet 16.09.2021).

29. Pallant J. SPSS survival manual. 3. utg. Maidenhead: Open University Press; 2007.

30. Riskin A, Erez A, Foulk TA, Riskin-Geuz K, Ziv A, Sela R, et al. Rudeness and medical team performance. Pediatrics. 2017;139(2):e20162305. DOI: $\underline{10.1542 / \text { peds.2016-2305 }}$ 